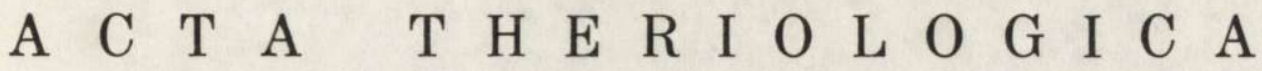 \\ VOL. 18, 4: 93-105 \\ BIAEOWIEŻA \\ April, 1973
}

\author{
Charles H. B UCKNER \& Jean-Marie BERGERON
}

\section{The Metabolic Energy Requirements of the Redback Vole}

[With 7 Tables \& 2 Figs.]

\begin{abstract}
Continuing studies on energy cycling through the bog ecosystems of southern Manitoba necessitate information on the energy budget of the redback vole, Clethrionomys gapperi loringi (B a il e y, 1897). Oxygen consumption, carbon dioxide production and urinary nitrogen excretion were measured for this species in a closed system respirometer over a narrow range of temperatures. At temperatures in the mid $50^{\circ}$ 's $\mathrm{F}$ oxygen consumption was $6.33 \mathrm{cc} / \mathrm{g}-\mathrm{hr}$, in the low $60^{\circ}$ 's it was $5.92 \mathrm{cc} / \mathrm{g}-\mathrm{hr}$ and in the high $60^{\circ} \mathrm{s} 4.59 \mathrm{cc} / \mathrm{g}-\mathrm{hr}$. Over these temperature ranges carbon dioxide production averaged $4.20,3.60$ and $2.90 \mathrm{cc} / \mathrm{g}-\mathrm{hr}$ respectively and urinary nitrogen $2.475,1.838$ and $1.821 \mathrm{mg}$ per hour respectively. Basal metabolism was approximately $3.97 \mathrm{Kcal} /$ day and active daily metabolism about $6.45 \mathrm{Kcal} /$ day based upon an average $19.1 \mathrm{~g}$ vole. The metabolic rates of males were slightly but significantly higher than females.
\end{abstract}

\section{INTRODUCTION}

The redback vole, Clethrionomys gapperi loringi (B a ile y, 1897) is an important component of the mammalian fauna of Manitoba bogs (B u ckner, 1958). Recent studies on the bioenergetics of this biotype have placed the major emphasis on the insectivores (B u c kner, 1964, 1966; Bergeron \& B u ckner, 1970): our attention is now begining to focus on the rodent species in the system.

The metabolism of terrestrial vertebrates can be measured directly or extrapolated from laboratory experiments (Golley, 1967). Direct methods such as the $\mathrm{D}_{2} \mathrm{O}_{18}$ technique ( $\mathrm{L}$ if $\mathrm{s}$ on et al., 1955), the use of radioactive isotopes ( $\mathrm{Odum} \& \mathrm{Golle} y, 1963)$, and telemetry have already shown their usefulness. The indirect methods used by $\mathrm{Brody}$ (1945) and Swift \& French (1954) are now well known and particularly useful in long term studies. The metabolism of small mammals is often determined by measuring the oxygen consumption (Morri- 
s o n, 1947), carbon dioxide production (B rody, 1945) and urinary-nitrogen excretion ( $\mathrm{H} \mathrm{a} \mathrm{w} \mathrm{k} \mathrm{et} \mathrm{al.,} \mathrm{1949).}$

It is known that the oxygen consumption can be based on body weight $(\mathrm{kg})$, metabolic size $\left(\mathrm{kg}^{2 / 3}\right.$ and $\left.\mathrm{kg}^{3 / 4}\right)$, and surface area $\left(\mathrm{m}^{2}\right) \quad(\mathrm{Ch} \mathrm{i} \mathrm{u} \mathrm{\&}$ $\mathrm{Hsi}$ e h, 1960), but it appears that the most useful equation was established by Brody (1945), where the relationship existing between metabolism and body weight is expressed by the formula $Y=a W^{b}$;

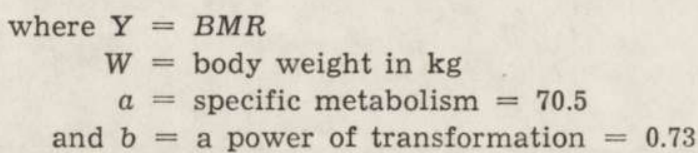

On the basis of such information, B u ckner (1964) calculated the daily metabolic requirements of four species of shrews (S. cinereus, $S$. arcticus, $M$. hoyi and $B$. brevicauda) to be $6.1,6.9,6.7$ and $9.7 \mathrm{Kcal}$ respectively. There were no differences between the sexes (B u c kner, 1964, Nelson \& Asling, 1962). Similar results had been calculated by P e a r s on (1947) by assuming a $R Q$ (respiratory quotient) of 0.80 . The energy requirements of short-tailed shrews found to be a little lower than previously reported ( $M$ artinsen, 1969), probably as a result of keeping them on a restricted diet. The metabolism of shrews can also change from season to season as shown by Gę bc zyński (1965); he found that $A D M R$ (average daily metabolic rate) was $8.8 \mathrm{Kcal}$ in summer, 8.5 in autumn and 7.5 in winter.

It is easy to understand that most studies were conducted on voles and mice since they are easier to keep in the laboratory. However, laboratory strains of wild populations showed metabolic differences from wild strains at temperatures of 10 to $20^{\circ} \mathrm{C}$ (G ó r e c ki, 1966). Measures of metabolic rates should be put on a $R M R$ (resting metabolic rate) or a $A D M R$ basis, although the latter form is more convenient for

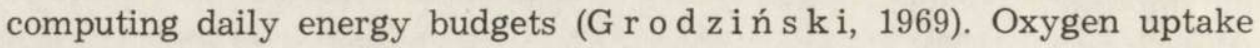
was found to be independent of the oxygen supply down to about $80 \mathrm{~mm}$ $\mathrm{Hg}$ during rest at $27^{\circ} \mathrm{C}$, to about $115 \mathrm{~mm} \mathrm{Hg}$ at $5^{\circ} \mathrm{C}$ (S e g rem \& $\mathrm{H}$ art, 1967). The RMR of European common voles, Microtus arvalis (P a llas, 1779) was found to vary in a straight-line fashion between 5 and $30^{\circ} \mathrm{C}$ ( $\mathrm{Trojan} \& \mathrm{Wojciechowska} \mathrm{1967a,} \mathrm{b);} \mathrm{at} \mathrm{tempera-}$ tures between 5 and $10^{\circ} \mathrm{C}$, the $R M R$ of females was higher than that of males. The oxygen consumption is known to increase with a decrease of ambient temperature, as shown by $\mathrm{D}$ a w s on (1955), $\mathrm{McNab}$ \& Morrison (1963), and Murie (1961). Fat deposits do not influence the metabolism of animals provided they stay within standard limits of 20 percent of the total body weight ( $\mathrm{M} \mathrm{c} \mathrm{N} \mathrm{a} \mathrm{b}, 1968$ ). 
The $D E B$ (daily energy budget) of bank voles was estimated at 10.2 Kcal during winter and $10.6 \mathrm{Kcal}$ during summer; 13.5 and $12.6 \mathrm{Kcal}$ for European common voles; 11.2 and $12.3 \mathrm{Kcal}$ for field mice (G r o-

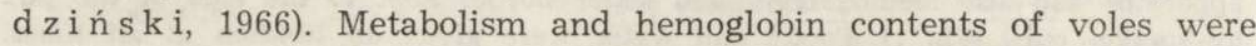
positively correlated except in winter, when high oxygen consumption was observed with the lowest blood hemoglobin content ( $\mathrm{S} \mathrm{h} \mathrm{e} \mathrm{v} \mathrm{ch} \mathrm{e} \mathrm{n-}$ k o, 1968). Harvest mice (Reithrodontomys fulvescens) showed a reverse energy expenditure pattern; in summer they consumed $5.6 \mathrm{Kcal} /$ day and in winter $8.8 \mathrm{Kcal} /$ day (G a e r tne r, 1968), an 80 percent increase in energy requirement.

Pregnancy and lactation are periods of intense energetic requirements for European common voles; pregnant females reached a consumption of $18.8 \mathrm{Kcal} /$ day and lactating ones $21.0 \mathrm{Kcal} /$ day (Trojan \& Wojci echowska, 1967); this represented increases of 23 and 37 percent energy expenditure compared to non-reproducing females. $\mathrm{K}$ a c z m a r$\mathrm{ski}$ (1966) estimated these two functions to require 32 and 122 percent more energy; he also showed that a litter of 4 would require a total of $364 \mathrm{Kcal}$ from the mother. Migula (1969) found that the production and nursing of one young vole required $75.9 \mathrm{Kcal}$.

Besides reproduction, the $D E B$ model is composed of nest life and search for food ( $\mathrm{Trojan} \mathrm{\&} \mathrm{Wojciechowska,1969).} \mathrm{It} \mathrm{was} \mathrm{found}$ that mice could spend $2.3 \mathrm{Kcal} /$ day in voluntary activity under different temperatures $\left(10-20-30^{\circ} \mathrm{C}\right)$, which made up 12,16 and 27 percent of their total daily expenditure. The working oxygen consumption of European common voles was 6.5 times the resting value while that of the bank voles was 7 times the resting value ( $\mathrm{J}$ a n ský, 1959). The act of swimming in white rats was found to consume 2 or 3 times the basic values ( $\mathrm{L}$ u s ti n e c, 1958). Similar results were obtained for bank voles (2.0-2.1) and field mice (1.6) (G rodziński \& Górecki, 1967).

The influence of nest life on the metabolism of animals was indirectly estimated. Darkness was found to decrease by 27 percent the oxygen consumption of European common voles ( $\mathrm{Trojan} \& \mathrm{Woj}$ ciechow$\mathrm{sk} \mathrm{a}, 1968 \mathrm{a}, \mathrm{b})$. The effect of huddling with 6 animals or more was also found to decrease the basic requirements of voles by 36 percent ( $\mathrm{Tr}$ ojan \& Wojciechowska, 1968). Using 4 animals at a time, Grodziński \& Górecki (1967) lowered the requirements of bank voles by 13 percent.

\section{MATERIALS AND METHODS}

The metabolism of redback vole was determined by their oxygen consumption. The apparatus was a modification of the closed-system automatic respirometer used by Buckner (1964). The metabolic cages consisted of battery jars con- 
taining a screen mesh floor partly covered underneath by a sheet of polyethylene plastic in order to protect the urinary excretions and soda lime pellets from fecal contamination and permit the latter ones to absorb water and carbon dioxide. The apparatus had also feeding trays and water bottles kept to the side of the jars by suction cups (Fig 1). Food ${ }^{1}$ and water were given ad libidum at all times. Some nesting materials were also included in the system.

The oxygen consumption was recorded automatically by a manometer-type-respirometer connected to an Esterline Angus Recorder; readings were corrected for each 24-hour period by the introduction of a thermobarometer in the water bath. The manometers were calibrated after each experiment to minimize the possible effect of the room temperature on the water.

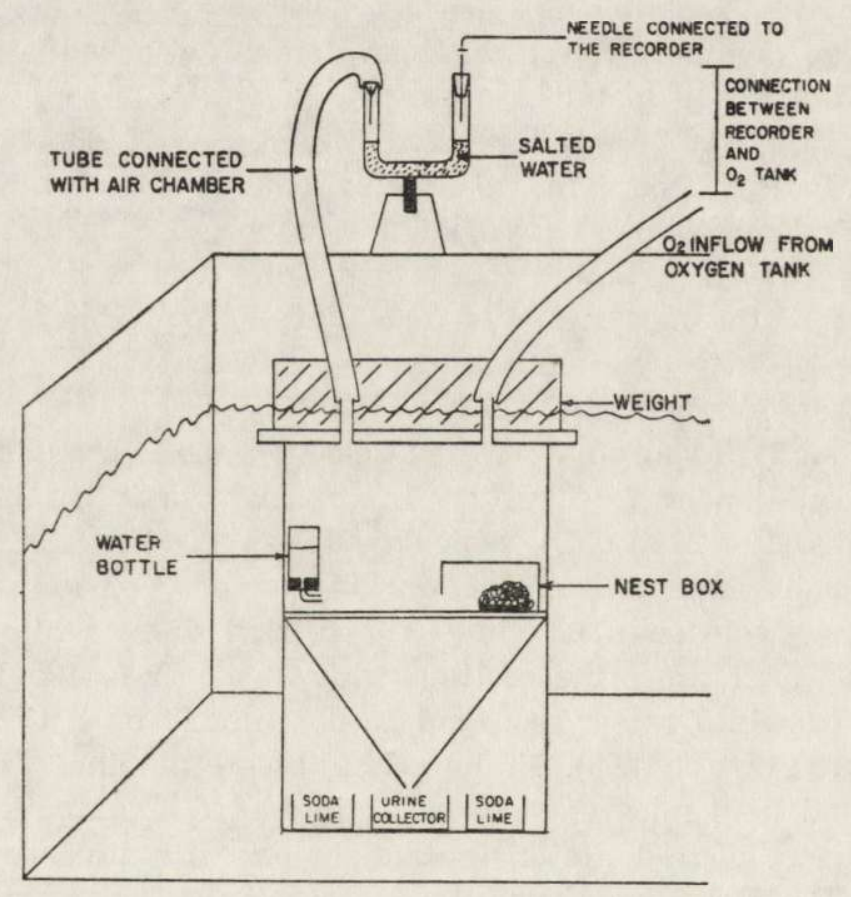

Fig. 1. Typical metabolism cage used to determine the metabolic requirements of redback voles.

The redback voles were captured partly in auxillary trap-lines of a permanent sampling plot of the Vertebrate Ecology Team, and partly from another plot near the Nuclear Research Center of Pinawa, Manitoba. The newly captured voles were brought to the laboratory and acclimatized to their new environment for a minimum of a month. They were then placed under experimental conditions for a one-day period and finally tested for another 24 hours. The metabolic cages were

1 The pig starter pellets used were composed of: $12.7 \%$ free water, $18.1 \%$ crude protein, $40.0 \%$ crude fat, $3.0 \%$ salt. 
Table 1

Mean values of oxygen consumption and carbon dioxide production of 20 redback voles tested under 3 different temperatures.

\begin{tabular}{|c|c|c|c|c|c|c|}
\hline \multicolumn{2}{|c|}{ Temperature } & \multirow{2}{*}{$\begin{array}{l}\text { Mean weight } \\
\text { of animals, } g\end{array}$} & \multicolumn{2}{|c|}{$\mathrm{HO}_{2}$ consumption } & \multicolumn{2}{|c|}{$\mathrm{CO}_{2}$ production } \\
\hline${ }^{\circ} \mathrm{F}$ & ${ }^{\circ} \mathrm{C}$ & & cc per hr & cc per g-hr & cc per $\mathrm{hr}$ & cc per g-hr \\
\hline $69-72$ & $20.6-22.2$ & 19.7 & $88.6 \pm 21.8$ & $4.59 \pm 1.02$ & $55.6 \pm 10.2$ & $2.88 \pm 0.51$ \\
\hline $62-64$ & $16.7-17.8$ & 19.0 & $111.9 \mp 22.7$ & $5.92 \pm 0.95$ & $67.1 \pm 8.8$ & $3.61 \mp 0.61$ \\
\hline $53-57$ & $11.7-13.9$ & 19.1 & $119.4 \pm 24.2$ & $6.33 \mp 1.26$ & $78.8 \pm 10.9$ & $4.17 \pm 0.65$ \\
\hline
\end{tabular}

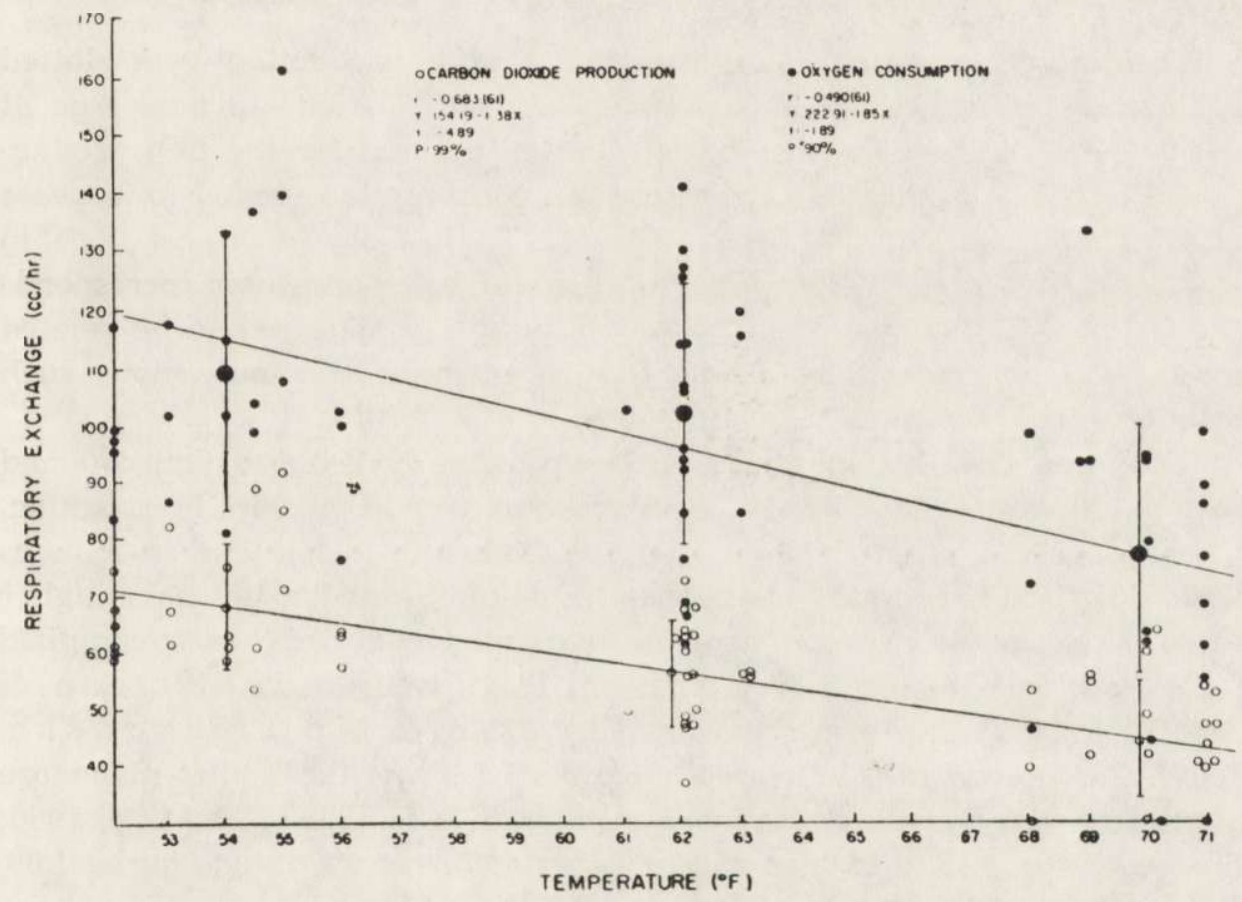

Fig. 2. Oxygen consumption, carbon dioxide production and temperature relationships of 20 redback voles.

immersed in a water bath kept at a constant temperature for the pricd of the experiment. The temperatures ranged from 53 to $73^{\circ} \mathrm{F}\left(11.6\right.$ to $\left.22.8^{\circ} \mathrm{C}\right)$. The caloric utilization in the metabolic process was calculated after Brody's technique (B r od y, 1945).

\section{RESULTS AND DISCUSSION}

The mean values of daily oxygen consumption and carbon dioxide production of redback voles are listed in Table 1. Oxygen consumption and carbon dioxide production increased as temperature decreased: the Acta theriol. 7 
oxygen consumption increased however, at a greater rate than did carbon dioxide production (Fig. 2), so that the $R Q$ values were lower than expected. The redback voles consumed daily $4.59 \mathrm{cc}$ of oxygen per $\mathrm{g}-\mathrm{hr}$ at $69-72^{\circ} \mathrm{F}, 5.92 \mathrm{cc}$ at $62-64^{\circ} \mathrm{F}$ and $6.33 \mathrm{cc}$ at $53-57^{\circ} \mathrm{F}$. The carbon dioxide production averaged $2.90,3.60$ and $4.20 \mathrm{cc} / \mathrm{g}-\mathrm{hr}$ for the same gradient of temperatures. The latter figures are surprisingly low when compared to those of Pearson (1962) and Morrison (1948). Assuming $R Q$ values of 0.70 and oxygen intakes such as shown above, the $\mathrm{CO}_{2}$ production should average $3.21,4.14$ and $4.43 \mathrm{cc}$ per g-hr at similar temperatures.

When oxygen consumption and carbon dioxide production were plotted against their respective temperatures, a linear relationship held true at the 90 percent level for the oxygen and 99 percent for the $\mathrm{CO}_{2}$ produc. tion (Fig. 2): as stipulated earlier, oxygen consumption tended to increase at a higher rate than $\mathrm{CO}_{2}$ production did. Table 2 shows the relationship existing between the respiratory quotients of voles and their corresponding $\mathrm{O}_{2}$ and $\mathrm{CO}_{2}$ values. The oxygen consumption appeared to be relater directly to the $R Q$ values while $\mathrm{CO}_{2}$ production did not show such relationship.

When analysed by age and sex groups, the oxygen consumption and carbon dioxide production gave interesting trends. Generally speaking, the average consumption of oxygen was higher in males than in females (Table 3). This is contrary to the general opinion that females have higher rates of oxygen consumption; such results have already been compiled for Peromyscus (Cook \& $\mathrm{Hannon}, 1954)$, tree-shrews (Nelson \& Asling, 1962), and common voles (Trojan \& Wojciechowska, 1967). On the contrary, our results support the hypothesis that males are more sensitive to mild stress when compared to females ( $\mathrm{Ch}$ it t y, 1960; $\mathrm{S} c \mathrm{~h}$ ell, 1967). The oxygen consumption of males was found to be 1.06 , 1.08 and 1.08 times those of females for the decreasing order of temperatures. Sub-adult males consumed more oxygen than did females, although the trend was less obvious among adults, where females consumed more at $62-64^{\circ} \mathrm{F}$ and much less at the two extremes. The carbon dioxide production was a little higher in males at both maximum and minimum temperatures. The production of males amounted to $1.02,0.96$ and 1.04 times those of females for the decreasing order of temperatures.

The carbon dioxide production of redback voles was found to be statistically related to the oxygen consumption at the two extreme temperatures $(P>99$ percent), while at the middle temperature range tested these two values were related only at the 93 percent level (Table 4 ). The relationship held true at all temperatures only when voles with $R Q$ of 0.73 and over were analysed $(P>99$ percent). The relationship appeared 
Table 2

Relationships between oxygen consumption, carbon dioxide production and the respiratory quotients $(R Q)$ of 20 redback voles.

\begin{tabular}{|c|c|c|c|c|c|}
\hline \multicolumn{2}{|c|}{ Temperature } & \multicolumn{2}{|c|}{$\mathrm{O}_{2}$ and $R Q$} & \multicolumn{2}{|c|}{$\mathrm{CO}_{2}$ and $R Q$} \\
\hline${ }^{\circ} \mathrm{F}$ & ${ }^{\circ} \mathrm{C}$ & $r$ & $y$ & $r$ & $y$ \\
\hline $69-72$ & $20.6-22.2$ & $-0.632^{*}$ & $169.20-125.32 x$ & 0.028 & --- \\
\hline $62-64$ & $16.2-17.8$ & $-0.788^{*}$ & $193.32-131.08 x$ & 0.223 & --- \\
\hline $3-57$ & $11.7-13.9$ & $-0.663^{*}$ & $257.86-207.28 x$ & -0.186 & --- \\
\hline
\end{tabular}

* Probability $>99 \%$ level.

Table 3

Mean values of oxygen consumption and carbon dioxide production of redback voles (analysed by age and sex).

\begin{tabular}{|c|c|c|c|c|}
\hline \multirow{3}{*}{$\begin{array}{l}\text { Temp. } \\
{ }^{\circ} \mathrm{F},\left({ }^{\circ} \mathrm{C}\right)\end{array}$} & \multicolumn{2}{|c|}{ Oxygen } & \multicolumn{2}{|c|}{ Carbon Dioxide } \\
\hline & \multirow{2}{*}{$\begin{array}{c}\text { Males } \\
\text { Sa Mean A }\end{array}$} & Females & Males & Females \\
\hline & & Sa Mean A & Sa Mean A & Sa Mean A \\
\hline $69-72$ & $83.6(8)^{*} 104.3(4)$ & $68.4(4) \quad 102.9(4)$ & $51.6(8) 64.6(4)$ & $46.7(4) \quad 63.2(4)$ \\
\hline $20.6-22.2)$ & $90.5(12)$ & $85.7(8)$ & $56.0(12)$ & $55.8(8)$ \\
\hline $6 ?-64$ & $109.4(10) \quad 128.2(3)$ & $88.0(5) \quad 136.1(3)$ & $63.6(9) \quad 73.2(3)$ & $67.8(5) 70.9(3)$ \\
\hline$(16.7-17.8)$ & $114.1(13)$ & $106.0(8)$ & $66.0(12)$ & $69.0(8)$ \\
\hline $5.3-57$ & $122.5(9) \quad 124.2(4)$ & $100.4(3) \quad 121.4(5)$ & $78,3(9) \quad 83.9(4)$ & $69.5(3) \quad 81.2(5)$ \\
\hline$(11.7-13.9)$ & $123.0(13)$ & $113.4(8)$ & $80.0(13)$ & $76.8(8)$ \\
\hline
\end{tabular}

* The numbers in parentheses refer to the number of animals tested at a given temperature. $\mathrm{Sa}$ - subadult, $\mathrm{A}-$ adult.

Table 4

Relationships between the oxygen consumption $(X)$ and the carbon dioxide production $(\mathrm{Y})$ of 20 redback voles.

\begin{tabular}{|c|c|c|c|c|c|}
\hline \multicolumn{2}{|c|}{ Tamperature } & cc & cc $\mathrm{CO}_{2} / \mathrm{hr}$ & \multicolumn{2}{|c|}{ cc $\mathrm{O}_{2} / \mathrm{g}-\mathrm{hr}$ vs ce $\mathrm{CO}_{2} / \mathrm{g}-\mathrm{hr}$} \\
\hline${ }^{\circ} \mathrm{F}$ & ${ }^{\circ} \mathrm{C}$ & $\boldsymbol{r}$ & $Y$ & $r$ & $Y$ \\
\hline $9-72$ & $20.6-222$ & $0.725^{*}$ & $2.56+0.34 \mathrm{X}$ & $0.674^{*}$ & $1.47+0.31 X$ \\
\hline $2-64$ & $16.7-17.8$ & $0.421^{1}$ & $4.76+0.17 X$ & $0.285^{2}$ & $2.48+0.19 X$ \\
\hline $3-57$ & $11.7-13.9$ & $0.82^{*}$ & $2.92+0.42 X$ & $0.863^{*}$ & $1.38+0.44 X$ \\
\hline
\end{tabular}

* Probability $>99 \%$ level. ${ }^{1}$ Probability $>93 \%$ level. ${ }^{2}$ Probability $>78 \%$ level.

to be weaker when oxygen and carbon dioxide values were converted to a volume per g-hr basis. This suggests that the weight of animals could have had an influence on either the $\mathrm{O}_{2}$ consumption or the $\mathrm{CO}_{2}$ values or on both of them. This contradicts the studies by $\mathrm{P}$ e a r s on (1962) when he mentioned that one need not correct the $\mathrm{CO}_{2}$ output for weight at various temperatures. 


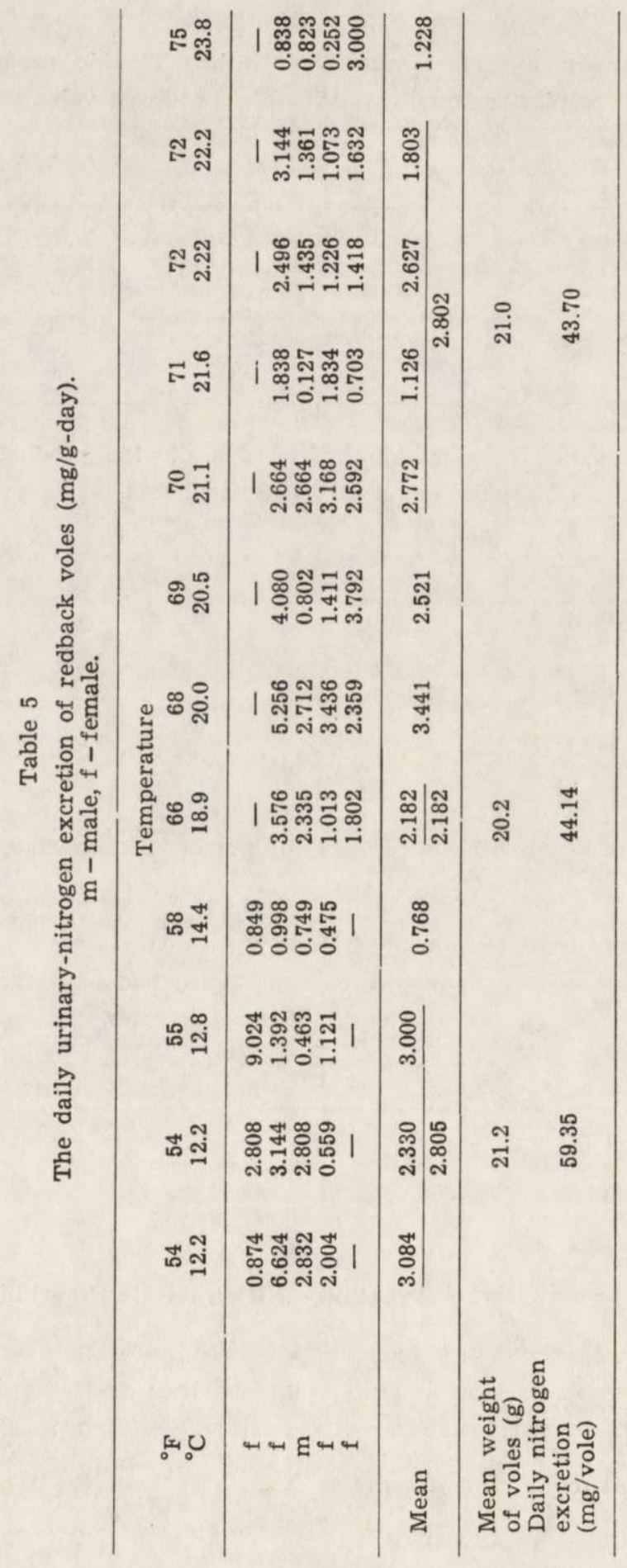


The daily urinary-nitrogen measurements were performed on 5 voles using a gradient of temperatures similar to that which was used for their metabolism studies (Table 5). The daily overall production averaged $46.9 \mathrm{mg}$ for animals weighing $20.9 \mathrm{~g}$. The fluctuations of the nitrogen measurements at different temperatures suggested no correlation between the latter values. However, a decrease in nitrogen excretion seemed to have occurred as temperature increased; the average nitrogen excretion at 54, 66 and $72^{\circ} \mathrm{F}$ indicated a slow decrease from 59.4 to $44.1 \mathrm{mg}$, to finally reach 43.7 at the higher temperature.

Table 6

The metabolic requirements of redback voles.

\begin{tabular}{lccc}
\hline Type of analysis & \multicolumn{3}{c}{ Temperature, ${ }^{\circ} \mathrm{F}\left({ }^{\circ} \mathrm{C}\right)$} \\
& $53-57$ & $62-64$ & $69-72$ \\
& $(11.7-13.9)$ & $(16.7-17.8)$ & $(20.6-22.2)$ \\
\hline $\begin{array}{l}\text { Mean daily urinary-nitrogen } \\
\text { excretion (mg/vole) }\end{array}$ & 59.35 & 44.14 & 43.70 \\
$\begin{array}{l}\text { Daily energy for protein catabolism } \\
\text { (Kcal) }\end{array}$ & 1.57 & 1.17 & 1.16 \\
$\begin{array}{l}\text { Daily metabolic requirements } \\
\text { (Kcal) }\end{array}$ & 13.25 & 12.53 & 9.91 \\
$\begin{array}{l}\text { SDA for proteins; 40\% of calories } \\
\text { derived from protein catabolism }\end{array}$ & 13.50 & 12.77 & 10.15 \\
(Kcal) & & & \\
\hline
\end{tabular}

Table 7

The metabolic requirements of redback voles using the calorific conversion of oxygen and $R Q$ values.

\begin{tabular}{|c|c|c|c|c|}
\hline \multicolumn{2}{|c|}{${ }^{\circ} \mathrm{F}$ Temperature } & \multirow{2}{*}{$\begin{array}{c}\underset{R Q}{\text { Maximum }} \\
.78\end{array}$} & $\begin{array}{c}\text { Daily } \mathrm{O}_{2} \text { consumtion } \\
\text { (liter) }\end{array}$ & $\begin{array}{l}\text { Calorific conv. } \\
\text { (Kcal) }\end{array}$ \\
\hline $69-72$ & $20.6-22.2$ & & 2.126 & 10.15 \\
\hline $62-64$ & $16.7-17.8$ & .76 & 2.688 & 12.77 \\
\hline $53-57$ & $11.7-13.9$ & .74 & 2.856 & 13.50 \\
\hline
\end{tabular}

Based on oxygen consumption, carbon dioxide production and urinary-nitrogen excretion, the metabolic requirements of redback voles are listed in Table 6 . In order to sustain their needs at a fairly low temperature, the voles need to increase their energy intake by 34 percent. At a temperature of $53-57^{\circ} \mathrm{F}$, which is thought to be about the yearly average temperature of the Manitoba bogs ( $\mathrm{B} \mathrm{u} \mathrm{c} \mathrm{kne} \mathrm{r,} \mathrm{1964),} \mathrm{the} \mathrm{voles}$ had to burn up to 12 percent of their daily energy budget $(D E B)$ to 
sustain their protein metabolism. The $D E B$ of redback voles fell within the limits set by several workers (K a c z marski, 1966, Trojan \& W ojci echow ska, 1967). However, the increase of their daily budget from $69-72^{\circ} \mathrm{F}$ to $53-57^{\circ} \mathrm{F}$ contradicted the results of $\mathrm{Gob} \mathrm{recki}$ (1968).

The requirements were also calculated using the calorific conversion of oxygen and maximum values of $R Q$. Although such estimations are of maximum values, they fall very close to those produced earlier (Table 7), that is within 2 percent of the former values. By substituting these values in B rody's (1945) equation, one can calculate the expected BMR. For redback voles weighing $19.1 \mathrm{~g}$, the basal requirements should amount to $3.97 \mathrm{Kcal} /$ day. Their calculated $A D M R$ at $70-72^{\circ} \mathrm{F}$ amounted to $6.45 \pm 2.48 \mathrm{Kcal} /$ day and the $A D M R$ corrected for $S D A$ (Specific dynamic action) of proteins averaged $5.98 \pm 2.48 \mathrm{Kcal} /$ day. The wide discrepancy between the observed and calculated values suggests that the measurements were not made in the thermoneutral zone, which is known to be above $72^{\circ} \mathrm{F}$ for voles. A simple $\chi^{2}$ analysis between the observed and calculated values supports this idea $\left(\chi^{2}=52.1>\chi^{2}\right.$ of tables at 36.2). It is believed however, that a good proportion of the population was in or near the thermoneutral zone. This is supported by the fact that if we do not consider the 3 voles which showed the highest individual $\chi^{2}$ the newly formed value amounted to 29.2 and proved to be statistically significant at the 99 percent level. This suggested then that 85 percent of the laboratory vole population could have reached a near BMR level. The discrepancy between the two values surely would have been reduced had the measurements been taken at a still higher temperature.

Acknowledgements: This project was supported jointly by the Canadian Forestry Service, The Zoology Department of the University of Manitoba and by National Research Council grants 311-1749-11 and 311-1749-05. W.G.H. Ives, Canadian Forestry Service, Edmonton, and W. J. Turnock, Canada Department of Agriculture, Winnipeg provided critical reviews of the program plan and the manuscript.

\section{REFERENCES}

1. Berger on J. M. \& Buckner C. H., 1970: Caloric values of some bog Lepidoptera. Manitoba Entomol., 4: 88-93

2. Brody S., 1945: Bioenergetics and growth. Reinhold Publ. Corp.: 1-1023. New York.

3. Buckner C. H., 1958: Mammalian predators of the larch sawfly in eastern Manitoba. Proc. 10th. Intern. Congr. Entomol., 4: 353-361.

4. Buckner C. H., 1964: Metabolism, food capacity and feeding behavior in four species of shrews. Can. J. Zool., 42: 259-279.

5. Buckner C. H., 1966: Populations and ecological relationships of shrews in tamarack bogs of southeastern Manitoba. J. Mamm., 47: 181-194. 
6. Chit ty D., 1960: Population processes in the vole and their relevance to general theory. Can. J. Zool., 38: 99-113.

7. Chiu C. C. \& H sieh A. C. L., 1960: A comparative study of four means of expressing the metabolic rate of rats. J. Physiol, 150, 3: 694-706.

8. Cook S. G. \& Hannon J. P, 1954: Metabolic differences between three strains of Peromyscus maniculatus. J. Mamm., 35: 553-560.

9. Daws o n W. R., 1955: The relations of oxygen consumption to temperature in desert rodents. J. Mamm., 36: 543-553.

10. Gaertner R. A., 1968: Seasonal variations in the energy budgets of the harvest mouse, Reithrodontomys fulvescens and the cottcn rat, Sigmodon hispidus. Diss. Abstr. B, 29: 412.

11. Gębczyński M., 1965: Seasonal and age changes in the metabolism an activity of Sorex araneus Linna u s, 1758. Acta theriol., 10, 22: 303-331.

12. Golley F. B., 1967: Methods of measuring secondary productivity in terrestrial vertebrate populations. [In: "Secondary productivity of terrestrial ecosystems", K Petrusewi cz, ed.], Państw. Wyd. Nauk.: 99-124. WarszawaKraków.

13. Górecki A., 1966: Metabolic acclimatization of bank voles to laboratory conditions. Acta theriol., 11, 18: 399-407.

14. Górecki A., 1968: Metabolic rate and energy budget in the bank vole. Acta theriol., 13, 20: $341-365$.

15. Grodziński W., 1966: Seasonal changes in daily energy budget of small rodents. Proc. IV Int. Biometeorol. Congr., New Brunswick, 1 pp.

16. Grodziński W., 1969: Two measurs of metabolic rate in common voles, Microtus arvalis (Pa l1.). [In: "Energy metabolism of farm animals", K. L. B la $\mathrm{ater}, \mathrm{G}$. T. Thor bek and J. Ki ela nowski, eds.]. Oriel Press Ltd.: EAAP Publ. No. 12: 399-400 Newcastle upon Tyne.

17. Grodziński W. \& Górecki A., 1967: Daily energy budget of small rodents. [In: "Secondary productivity of terrestrial ecosystems", K. Petrus ew i cz, ed.], Państw. Wyd. Nauk.: 295-314. Warszawa-Kraków.

18. H a w k P. B., Oser B. L. \& Summers on W. H., 1949: Practical physiological chemistry. Blackiston Co.: 1-1439. Philadelphia.

19. J a n s k ý L., 1959: Working oxygen consumption in two species of wild rodents (Microtus arvalis, Clethrionomys glareolus). Physiol. Bohemosl., 8, 5: 472-478.

20. Ka czmarski F., 1966: Bioenergetics of pregnancy and lactation in the bank vole. Acta theriol., 11, 19: 409-417.

21. Lifson N., G ord on G. B. \& M c Clintock R., 1955: Measurement of total carbon dioxide production by means of $\mathrm{D}_{2} \mathrm{O}_{18}$. J. Appl. Physiol. 7: 704-710.

22. Lustinec K., 1958: Oxygen consumption in rats during swimming. Physiol. Bohemosl., 7, 2: 208-215.

23. M a r tins e n D. L., 1969: Energetics and activity patterns of short-tailed shrews (Blarina) on restricted diets. Ecology, 50, 3: 505-510.

24. $\mathrm{M} c \mathrm{~N}$ a b B. K., 1968: The influence of fat deposits on the basal rate of metabolism in desert homoiotherms. Comp. Biochem. Physiol., 26, 1: 337-343.

25. $\mathrm{McNab}$ B. K. \& $\mathrm{M}$ orris on P., 1963: Body temperature and metabolism in subspecies of Peromyscus from arid and meso environments. Ecol. Monogr., 33: $63-82$.

26. Migula P., 1969: Bioenergetics of pregnancy and lactation in European common vole. Acta theriol., 14, 13: 167-179. 
27. Morris on P. R., 1947: An automatic apparatus for the determination of oxygen consumption. J. biol. Chem., 169: 667-669.

28. M orris on P. R., 1948: Oxygen consumption in several small wild mammals J. cell. comp. Physiol., 31: 69-96.

29. Murie M., 1961: Metabolic characteristics of mountains, desert and coastal populations of Peromyscus. Ecology, 42: 723-740.

30. Nels on L. E. \& Asling C. W., 1962: Metabolic rate of tree-shrews (Urogale everetti). Proc. Soc. exptl. Biol. Med., 109, 3: 602-604.

31. Odum E. P. \& Golle y F. B., 1963: Radioactive tracers as an aid to the measurement of energy flow at the population level in nature. [In: "Radioecology «, V. Schultz \& A. W. Klement, eds.]. Reinhold Publ. Corp.: 403-410, New York.

32. Pear s on A. M., 1962: Activity pattern, energy metabolism and growth rate of the voles C. rufocanus and C. glareolus in Finland. Ann. Zool. Soc. Vanamo, 24: $1-58$.

33. P e a r s o n O. P., 1947: The rate of metabolism of some small mammals. Ecology, 28: $127-145$.

34. S c hell R. E., 1967: Note on sex differences in response to stress in rats. Psychol. Rep. 20: 1201-1202.

35. Segrem N. P. \& H a r t J. S., 1967: Oxygen supply and performance in Peromyscus. Metabolic and circulatory response to exercise. Can. J. Physiol. Pharmacol., 45, 3: $531-541$.

36. Shevchenko N. T., 1968: Seasonal changes of metabolism and some haematologic indices in Microtus arvalis $\mathrm{P}$ a 1l. under conditions of the Ukraine. Vest. Zool., 3: 33-36. Kiev. [In Russian with English summ.].

37. Swift R. M. \& French C. E., 1954: Energy metabolism and nutrition. Washington Press: 1-264.

38. Trojan P. \& Wojciechowska B., 1967a: Resting metabolic rate in the European common vole, Microtus arvalis ( $\mathrm{P}$ a 1l.) in different ambient temperatures. Ekol. pol. A, 15, 43: 803-810.

39. Trojan P. \& Wojciechowska B., 1967b: Resting metabolic rate during pregnancy and lactation in the European common vole, Microtus arvalis ( $\mathrm{P}$ a 11 .). Ekol. pol. A, 15, 43: 811-817.

40. Trojan P. \& Wojciechowska B., 1968a: The effect of huddling on the resting metabolism rate of the European common vole, Microtus arvalis ( $\mathrm{P}$ a 11.). Bull. Acad. Pol. Sci., Cl. II, 16, 2: 107-109.

41. Trojan P. \& Wojciechowska B., 1968b: The influence of darkness on the oxygen consumption of the nesting European common vole, Microtus arvalis (P a 11.). Bull. Acad. Pol. Sci., Cl. II, 16, 2: 111-112.

42. Trojan P. \& Wojciechowska B., 1969: Ecological model and tables of the daily costs of maintenance $(D E B)$ of Microtus arvalis (P a 11.). Ekol. pol. A, 17, 17: $313-342$.

Received, November 14, 1972.

Chemical Control Research Institute

25 Pickering Place

Ottawa K1A OW3

Department of Biology

University de Sherbrooke

Sherbrooke, Quebec. 
Charles H. BUCKNER i Jean-Marie BERGERON

\section{ZAPOTRZEBOWANIE ENERGETYCZNE NORNICY}

\section{Streszczenie}

Badania przepływu energii w bagiennych ekosystemach poludniowej Manitoby wymagają informacji o budżecie energetycznym nornicy, Clethrionomys gapperi loringi (B aile y, 1897). Zmierzono zatem zużycie tlenu, produkcję $\mathrm{CO}_{2}$ i wydalenie azotu $\mathrm{z}$ moczem $\mathrm{u}$ tych nornic w respirometrze systemu zamkniętego (Ryc. 1) i w wąskich granicach temperatury otoczenia. Zużycie tlenu $\mathrm{w}$ temperaturach ca $12-14^{\circ} \mathrm{C}$ wynosiło $6,33 \mathrm{~cm}^{3} / \mathrm{g}-\mathrm{hr}$, w ca $17-18^{\circ} \mathrm{C}-5,92 \mathrm{~cm}^{3} / \mathrm{g}-\mathrm{hr}$ a w temperaturach około $21-22^{\circ} \mathrm{C}-4,59 \mathrm{~cm}^{3} / \mathrm{g}-\mathrm{hr}$ (Tabela 1 ). W tych samych zakresach temperatur produkcja dwutlenku węgla wynosiła odpowiednio $4,20,3,60$ i $2,90 \mathrm{~cm}^{3} / \mathrm{g}-\mathrm{hr}$ (Tabela 2) a azotu w moczu odpowiednio 2,475, 1,838 i 1,821 mg/hr (Tabela 5). Dla przeciętnej nornicy o ciężarze ciała $19,1 \mathrm{~g}$ metabolizm podstawowy $(B M R)$ wynosił $3,97 \mathrm{Kcal} / \mathrm{dzień}$ a średni metabolizm dobowy $(A D M R)-6,45 \mathrm{Kcal} / \mathrm{dzień}$ (Tabele 6, 7). Tempo metabolizmu samców było istotnie wyższe niż samic (Tabela 3). 